\title{
Coping with the Training of Muslim Leaders in Belgium
}

\author{
Andrea Rea
}

Since many years, the training of imams has been put at the center of the policy agenda in several European countries. Because in Belgium religion classes are part of the compulsory program of pupils, the training of imams is coupled with the training of professors of religion. Recently, proposals to organize these trainings by universities have been submitted to the political arena. These proposals aim at introducing, on the one hand, classes of French and Dutch languages and, on the other hand, classes on Belgian society and legislations. As such an issue is under the competence of regions, debates and proposals diverge significantly in Flanders and in the French-speaking part of the country. The paper analyzes the challenges for dealing with this issue in the two parts of the country. It analyzes the positions, the controversies and the proposals of state and nonstate actors involved in this debate. The author stresses how the state plans to organize these trainings and how the state justifies its intervention in an issue that is usually a domain of competence of the hierarchy of the "Church" or the self-organization of the Islam.

Andrea Rea is Professor at the Université libre de Bruxelles. He is the Director of the Group for Research on Ethnic Relations, Migrations and Equality (GERME, website: germe.ulb.ac.be) and the Dean of the Faculty of Social and Political Sciences at the Université libre de Bruxelles. His research interests focus on the integration of migrants on the labour market, the political participation of ethnic minorities, the European policies of immigration and integration and the European border control policies.

\section{Introduction}

For many years, the training of Muslim leaders (imams, teachers of Islamic religious education, Muslim counselors) has been on the political agenda in Belgium. At present no training program for Muslim leaders has been formulated by the representative body of the Muslim faith, the Muslim Executive of Belgium (MEB), or submitted by them for recognition by the public authorities. It follows that in the absence of such a program, the Muslim community has no institutions for the purpose of leadership training, unlike other recognized religions and secularist organizations. The lack of this instrument creates an unjustified inequality between the religions and, in addition, contributes to a climate of suspicion and distrust on the part of the public authorities towards some imams, who are considered as potentially able to feed the growth of fundamentalism. In order to respond to this problematic situation, the Belgian state has taken initiative to 
bring leadership training programs into existence in collaboration with the MEB. The question of the legitimacy of state involvement immediately arises given that the Belgian Constitution guarantees the separation of state and religion.

This paper puts forward an analysis of how Muslim leadership training is being developed in Belgium. The analysis describes the model put in place and the path that led to the current situation, as well as explaining the main factors that led to this particular outcome. Given that the question of training is dependent on the relationship between the state and religions, the paper will first of all analyze this relationship and the specific question of the recognition of the Muslim faith. It will then analyze how the state has been able to justify its involvement by exploiting the possibilities offered by the Constitution and the organizational weaknesses of the Muslim communities.

The main thesis is that Belgian state intervention in the training of Imams and teachers of Islamic religious education is justified primarily by a logic of security that treats training for imams as an instrument to combat Muslim fundamentalism, guarantee public order and help to build an European Islam. It is thus control, rather than the improved educational standards, the main objective of the policy. Other factors contributing to state intervention are the climate of Islamophobia, fragmentation of the Muslim community and the weak leadership of the officially recognized representation of Muslims, the Muslim Executive of Belgium.

This analysis touches upon the issue of institutional responses to religious diversity in three ways. Firstly, the analysis recognizes that the institutional arrangements between the state and religious communities are key in shaping the national response to the problematic of training Imams. Secondly, the paper pays close attention to the institutions that represent the Muslim community and how the specific form of institutionalization that emerged in Belgium influences the policy on training of imams. Thirdly, the paper also highlights how the particular solution chosen impacts on institutions of the host society, in particular the university, which acquires an important role as a co-producer of the new policy together with the state, Islamic associations and the Muslim leadership. At the end, governments at the federal and regional level set up Commissions made up of representatives of Muslim communities, representatives of the universities, and experts showing the central role played by meso-level institutions on this issue.

\section{The relationship between religions and the state in Belgium}

In 1831, the Constituent Assembly settled the basis for the politics of religion in Belgium. The Belgian constitution establishes freedom of religion and of public worship (article 19), and also the freedom not to practice any religion (article 20). It also provides for the independence of religion in respect of the state (article 16), specifically by forbidding the state to interfere in the appointment of ministers of 
religion or to prevent correspondence between ministers of religion and their superiors. In terms of finance, article 181 of the Constitution provides that salaries and pensions of ministers of religion are paid by the state and registered annually in its budget. This measure was taken to compensate for the confiscation of goods from the Catholic Church during the revolutionary period and for the abolition of various sources of income, which had previously been paid to the Church. Apart from this, the communes took financial responsibility for the maintenance of religious buildings (Catholic churches, synagogues and Protestant churches).

The model chosen is both close to and distant from the French Concordat of 1801. It is relatively close in its acceptance that the "social utility of religion" (de Coorebyter 2005) consists essentially in the maintenance of the established order. However, the model is distant from the French Concordat because the latter set up mechanisms of control of religion which were not copied in Belgium (Tihon 2005). The young Belgian state thus put in place a relatively generous funding system, but without attaching means of control as the State does not control the Church expenditure, which made the system completely original for its time (Sägesser / de Coorebyter 2000). This particular system resulted from the unionist spirit at the time of independence between the two main pillars (Lijphart 1981) of the Belgian state: liberals, who were essentially secularist, and Catholics. So, from the beginning, the young Belgian state funded religion in the framework of a policy aiming to guarantee social order, reinforce public morality, and build respect for the law, property, goods and persons (de Coorebyter 2005). In return, recognized religions were protected and funded. With this model, Belgium avoided choosing between a state-controlled, state-financed Church and a free Church with no public funding.

The recognition of the Catholic, Protestant and Jewish religions predated independence. The Anglican religion was recognized at the time of the adoption of the law of $4^{\text {th }}$ March 1870 which distinguished between the temporal and spiritual aspects of a religion. Only the temporal aspect of a religion is officially recognized and financed by the state. Although there is no law establishing the conditions for a religion to be recognized, four criteria are traditionally used by the state: a) having a minimum number of adherents, $b$ ) being structured in such a way as to have a representative body which can represent the religion concerned in its relations with the state, $c$ ) being established in the country for a sufficient length of time and d) being of social benefit and not carrying out any activities which are harmful to public order (Sägesser / de Coorebyter 2000).

The representative body is responsible for the temporal administration of the religion. Founded principally on the institutional structure of the Catholic Church, the criteria of having a representative body poses problems to religions which are less centralized than Catholicism. It is expected of the representative body that it should bring together as many as possible of the local communities of the religion concerned. The recognition of religions has therefore led the Protestants and the Jews to create administrative structures allowing contact with the 
public authorities, the Administrative Council of the Protestant and Evangelical Religion and the Jewish Central Consistory of Belgium, respectively.

This model of organization of the relations between religions and the state has continued without fundamental change up to the present, showing a strong salience of path dependency (Piersons 1994). The funding of religions has been organized on the basis of instruments created in the early $19^{\text {th }}$ century. The recognition of new religions such as Islam in 1974, Orthodoxy in 1985 and more recently the financing of secularist organizations in 1993 extended the model. Nevertheless, a change took place following the Schools Pact of 1958. Article 24 of the Constitution, as interpreted in a law of 1959, provides that public schools must offer pupils the choice, throughout the whole of their compulsory education, of classes in any one of the recognized religions or in non-confessional ethics. The representative body of each religion is to put forward to the state its nominations of teachers of religious education.

Thus, each religion must have a representative body, whose principal tasks are: a) to nominate ministers of religion, religious counselors (to hospitals, prisons, the army etc.), teachers and inspectors of religious education, etc. (Beumier 2006 and Sägesser 2012); to organize training for these various professional groups, b) to put forward local communities (churches, mosques, etc.) to the public authorities for recognition, and c) to validate the religious education program.

In 2001, Belgian federalism also went through a change in the division of powers between different levels of government. The federal state has jurisdiction firstly over the recognition of religions and their representative bodies and secondly over the creation of paid positions for ministers of religion, also over their salaries and pensions and those of delegates from secularist organizations. The regions have jurisdiction over the recognition of places of worship (churches, mosques, etc.). Communes (for Catholicism, Protestantism, Judaism and Anglicanism) and provinces (for Islam and Orthodoxy) make financial contributions for the maintenance of places of worship and provide housing for ministers of religion. To coordinate the recognition of places of worship by the region and the creation of paid positions for ministers of religion at federal level, consultation mechanisms have been put into place between the different levels of government.

There is thus a degree of consensus in Belgium regarding, on the one hand, the social utility of "communities of conviction", whether religious or not, as a means of moral and spiritual support for the population; and on the other hand, the principle of public funding for these communities. As for the dimension of "public order", this has become increasingly important since the end of the twentieth century. The primary concern is no longer Catholicism, as it was in the nineteenth century, but Islam. The Belgian legal framework has allowed the recognition of Islam and its integration using existing policy instruments, without the need to search for new methods of intervention. At the same time, Islam has had to adapt to integrate into the system: the organization of Muslim communities, the iden- 
tification and specific role of ministers of religion, the contribution to social cohesion and to "religious peace".

\section{The recognition of Islam}

The recognition of Islam was established by law on 19 July 1974. However, the institutionalization of the recognition of Islam was slow to take effect. An operating subsidy was not granted to a representative body of Islam until the mid1990s and the first salaries for imams were not paid until 2006, which was also the year that the first mosques were officially recognized. Only the organization of Islamic religious education in public schools was achieved rapidly, from 19751976. The time elapsed from the recognition of Islam to the implementation of that recognition is largely due to the wide diversity of Muslim communities and the mutual distrust between these communities and the government. As in other countries (Fetzer / Soper 2005; Husson / Dury 2006; Potz / Wieshaider 2004), the Belgian authorities have been confronted with the difficulty of identifying a representative and uncontested interlocutor for the various Muslim communities.

From the beginning, the question of the recognition of a representative body for the Muslim religion has been at the heart of the political debate (Kanmaz 2002; Sägesser / Torrekens 2008). The state has found it very difficult not to exceed its authority in the matter. In 1978, the state granted the temporal management of the religion to the Islamic and Cultural Center (ICC), the main interlocutor with Belgian public authorities well before the official recognition of Islam. This institution played a central role in the organization of the first Islamic religious education classes in public schools. Despite being the product of diplomatic agreements between Belgium and Saudi Arabia, the ICC was distrusted by the political parties due to its joining the World Islamic League in 1982 and due to the fear of Islam which became widespread in public opinion during the 1980's (Bastenier / Dassetto 1987). In 1985, the Minister of Justice, Jean Gol, drew up a Royal Decree creating a High Council of Muslims for Belgium, to be responsible for the temporal management of Islamic communities. The objective of this law was to replace the Islamic and Cultural Center, which was too controversial and unrepresentative, by a body which would be representative of Islam in Belgium. This proposed legislation was rejected by the Council of State because the Constitution does not authorize the government to act on its own authority to create an institution responsible for representing believers (Blaise / de Coorebyter 1993).

In 1989, the Royal Commissariat on Immigrant Policy (RCIP) was set up to give advice on an inclusive integration policy. In its first report, the RCIP (1989) proposed the creation of a democratically elected and representative organization for Islam in Belgium which would be the interlocutor with the state. This High Council of Muslims for Belgium should be made up of representatives elected 
through the mosques and coopted representatives. This proposal, which provoked much controversy, was not adopted by the government. In March 1990, the government relieved the Islamic and Cultural Center of its powers to nominate teachers of religious education and in June 1990 it created a Provisional Council of Elders to serve for two years. This council was given the task of submitting a proposal to the government for the creation of a representative leadership body. The state was able to create this council because the council was not itself a leadership body but a kind of consultative council of which the members appointed by the government were more representative of the lobby groups of Belgian society rather than the diversity of Muslims in Belgium (Renaerts 1996). This council was never accepted by Muslims. An important task of the council was the handling of urgent business, especially the nomination of teachers of religious education. On this matter, there was a marked difference of views between the Moroccans and the Turks. The former preferred to nominate people settled in Belgium, whereas the latter preferred to bring teachers from Turkey, thereby following the approach of the Diyanet, the Turkish Ministry of Religious Affairs.

Meanwhile, the Islamic and Cultural Center was not inactive. On the basis of the proposal of the RCIP, it established an electoral procedure for the selection of religious representatives through the mosques. 300000 Muslims participated in this process. The elections were held in January 1991, but their results were not valid because the state did not recognize the process as this will be explained later. Nevertheless, it gave rise to the creation of a High Council of Muslims which was not recognized as interlocutor by the state. In spite of this lack of recognition and the absence of controls of the electoral procedure, the authorities could not completely ignore this process of self-organization.

The Center for Equal Opportunities and Opposition to Racism (CEOOR), which succeeded the RCIP, found a way through the impasse in 1993. They opened negotiations between the main factions of Islam in Belgium to enable the formation of a Constituent assembly, an authority which the faithful would be able to recognize as legitimate (Blaise 1998). It was set up in the spring of 1993 and was made up of 51 people. It elected a Muslim Executive of Belgium (MEB) of 17 people who, after the Minister of Justice gave approval for each of the individual members, was recognized by the government in 1994. The project was therefore built from the bottom up, but with steering and controls by the state, and the essential involvement of a broker (Kingdon 1984), the CEOOR. This MEB coexisted with the High Council of Muslims created by the elections organized by the Islamic and Cultural Center in 1991. The latter ceased its activities particularly because its president became the president of the MEB. This body nominated teachers of religious education as well as religious counselors for hospitals and prisons. Its work was monitored by the CEOOR.

On 12 June 1998, the Council of Ministers adopted the proposal to organize elections for the appointment of a new Muslim Executive of Belgium. These elections took place on 13 December 1998. An Assembly of 51 elected members 
and 17 co-opted members was to be established and to elect an executive, which was recognized as the leadership body. All Muslims resident in Belgium for more than a year were allowed to register on the electoral lists. The voting was carried out either in a mosque or in a public institution. The candidates were required to be at least 25 years old, to be resident in Belgium for at least five years, to enjoy civil rights, to know one of the official languages of the country, and not to be appointed to any political or diplomatic role. In addition, they were required to have a high school diploma. Of the 72000 registered on the electoral lists, 42000 cast a vote. The result of the elections was confirmed on 9 January 1999 and in February a new Muslim Executive of Belgium of 17 members (7 Moroccans, 4 Turks, 3 other nationalities, and 3 converts) was proposed to the Minister of Justice. However one of the elected Moroccans was turned down following an unfavorable decision by State Security. The screening imposed by the state brought about much ill feeling among Muslims, especially since there was no legal basis whatsoever for the screening and the criteria applied were never explained. Since this security check had no legal basis, a new law was adopted on 3 May 2005 establishing procedures for a security check of members of the Muslim Executive of Belgium, showing once again the security dimension inherent to this specific policy. Further elections took place in 2005 , in a climate of intense conflict between opposing currents at the heart of the Muslim community. The call for a boycott of these elections, predominantly on the Moroccan side, led to a strong overrepresentation of Turks among those elected to the new MEB. To avoid the errors of the past and consolidate the achievements of the executive, the electoral process in 2014 was based on a different procedure, closer to that used by the Protestant and Jewish religions. A charter of affiliation to the process of renewal was submitted to the 292 mosques in the country, and they all ratified it ${ }^{1}$. Of those, 284 sent delegates to the General Council of Muslims in Belgium. This General Council appointed 60 members to the General Assembly, who in turn appointed 15 members of the Executive, who co-opted two extra members. The new executive has been in place since 30 March 2014.

\section{Conditions of institutionalization}

How was the transition achieved from the dramatization of finding a Muslim representative body to its institutionalization? The initial problem resided in the lack of a religious hierarchy in Islam and the need for the state to have an interlocutor. However, the international and diplomatic approach whereby the state gave the role of leadership body to the Islamic and Cultural Center delayed the

1 See "Projet de Renouvellement de l'Organe Représentatif du Culte Musulman en Belgique (ORCMB)" dated May 2010 - http://mediation.blogs.lalibre.be/media/02/00/ 1782274688.pdf (24 July 2015). 
creation of a grouping or federation of mosques, in summary the self-organization of Islam in Belgium. At the same time, the fragmentation of local Muslim communities made an international resolution of the matter seem attractive. The mosques, through their diversity and weak organization, allowed the Islamic and Cultural Center to have the monopoly of contact with the Belgian authorities. When the state in 1990 removed the body it had appointed in the absence of an alternative, it never considered allowing Muslims to put together a leadership body autonomously, and this was for reasons of ideology and of public security. Islam is an immigrant religion, and the fear of Islam has taken hold of Belgian public opinion since $1986^{2}$. Since then, immigrants and Islam are considered potential "threats" which require state control. This security-oriented approach has never disappeared ever since the institutionalization of the MEB in 1999. This is demonstrated by the practice of screening elected delegates by State Security. The atmosphere continues to be dominated by suspicion, and even more so since 11 September 2001 (Bousetta 2002) and with the recent radicalization of some Muslims.

The conflict between the state and local Muslim communities was at its worst when the government relieved the Islamic and Cultural Center of its responsibilities and created the Provisional Council of Elders. Distrusting the mosques, the government didn't allow them any role in organizing their own religion. By setting up the Provisional Council of Elders, it created an interlocutor in its own image, and by doing so, it cut itself off from Muslims. The state showed contempt not only for the mosques but also for Muslims, by creating an artificial body with no legitimacy which undermined Muslim religious identity.

The delay in settling the matter was also due to a lack of consensus at the heart of the political parties. The liberal and therefore secularist ministers who had responsibility for this issue during the 1980s rarely showed any conciliation towards the Muslim communities. The lack of a political solution was no problem for anyone except a small marginalized group, namely the teachers of Islamic religious education who did not enjoy the same status as their colleagues from other religions, and the imams who still didn't receive a state salary. In 1989, the RCIP proposal put the question back on the political agenda although its substance was fiercely criticized, especially by liberal and socialist secularists. From when it was first set up, the CEOOR took this issue in hand and took up a mediating role between the High Council of Muslims, unrecognized by the state, and the Minister of Justice. Although it was not in conformity with the law, the electoral procedure

2 After American bombing on Tripoli resulting from increasing tensions between the United States and Libya, some Muslims organize in Brussels a demonstration on April 20th, 1986. During this demonstration, some Muslims shout "Allah U Akbar" and raise portraits of Ayatollah Khomeiny and of Colonel Kaddhafi. For the Belgian media, this was the starting point of the visibility of Muslim fundamentalism. (Dassetto / Bastenier 1987). 
of the High Council demonstrated a political legitimacy which the government could not ignore. There therefore began a phase of negotiations which succeeded in creating the Constituent Assembly. The Muslim Executive which was drawn from this constituent assembly was set up in October 1994 for a period of one year and was based on long negotiations amongst most of the factions present in the Muslim communities (CEOOR 1995). The CEOOR proposed a pragmatic procedure to the Minister of Justice, which consisted in putting the working of the executive to the test, and evaluating their activities.

The President of the Executive, previously the President of the High Council of Muslims, encouraged the democratically elected High Council to change its strategy in relation to the Belgian authorities and accept the mediation of the Center, because he realized that Islam was not regarded sympathetically by the Belgian population and that it would be better to pursue dialogue and negotiation. On the side of the political authorities, it was the directors of RCIP (Paula D'Hondt) and of CEOOR (Johan Leman), both close to the Flemish Christian Democratic Party, who pushed for progress with two Ministers of Justice successively, both of them also Christian Democrats. The Flemish Christian Democrat Minister, Stefan De Clerck, made the commitment to finding a solution which would require both new elections and a relative guarantee that religious extremists would be absent from the elected body. In other words, the government followed the guidelines of the proposal from the RCIP, which it had not been politically possible to implement at the time it was first put forward.

What led to the opening up of political opportunity? Three factors were essential (Rea 2000). The first was the most institutional element of the representation of Islam, namely the attitude of the High Council of Muslims, elected but unrecognized. In its strategy it showed great pragmatism which fits relatively well into the Belgian political ethos that avoids French-style ideological conflict. In addition, the transition from confrontation to negotiation allowed the internal organization of the diversity within the Muslim communities. Tactically, by choosing as president a Belgian convert, the Muslim Council disarmed racist and stigmatizing reactions. The second factor was the essential role played by the RCIP and the CEOOR. Their work as brokers in this policy area between 1989 and 1998 allowed the creation of a space for discussion between the Muslim leaders and the responsible politicians. However, their role was above all essential in changing the focus of this policy. The Flemish Christian Democrat individuals leading these two institutions and the Christian Democrat Minister, by presenting the policy in terms of the objective of immigrant integration, rather than in terms of recognition of a religion and thereby deepening the traditional confessional cleavage of Belgian society, defused the most obvious objections of the secularists in regard to this matter. Finally, the third, more structural factor was the transformation of immigrants into Belgian citizens. Between 1991 and 2012 more than 750.000 foreigners became Belgian, and especially in Brussels where 200.000 
people with Moroccan and Turkish background became Belgian ${ }^{3}$. These people are now a group of Belgian citizens of Muslim faith, Belgian citizens who undeniably have Muslim identity. The growth in the numbers of those who have acquired Belgian nationality has stimulated something of a competition between the political parties to attract this new electorate, including those parties which were the most reluctant to recognize a Muslim leadership body (the francophone socialists and the liberals). Since 1994, the number of Muslims elected to the parliamentary assemblies has increased steadily and the voice of Belgians of Muslim faith has grown more and more powerful (Jacobs et al. 2010).

\section{Islam and Muslim leadership in Belgium}

Islam became a major religion in Belgium due to the arrival of immigrant workers at the beginning of the 1960s. After the signature of bilateral agreements with Morocco and Turkey in 1964, many immigrant workers from these two countries settled in the three regions of Belgium. During the 1970s, family reunification and the high birth rate of Moroccan and Turkish families led to a rapid increase in the Muslim population. One of the features of Moroccan and Turkish immigration is that it did not cease when labor immigration was brought to an end. More than $40 \%$ of new residence permits granted each year are connected to family reunification (CEOOR 2013). Among these new arrivals, there are many Moroccans and Turks who owe their mobility to an international marriage. Moreover, there are also immigrants arriving from other countries with a Muslim majority: Albania, Pakistan, Iran, and Iraq. However, the people coming from these countries mostly arrive in Belgium as asylum seekers. In the absence of census figures for the number of Muslims in Belgium, Hertogen (2008) proposed a method based on two indicators. He identified the population having an immigration background from each Muslim country and applied a weighting based on a German survey measuring the proportion of people in Germany with that background who identified themselves as Muslim ( $74 \%$ for Turks, $73 \%$ for Moroccans). His data is from the year $2010^{4}$. He estimated 685684 Muslims (315 580 of Moroccan origin, 174656 of Turkish origin and 195447 of other nationalities). Thus an estimated $6.3 \%$ of the Belgian population is Muslim: $4.5 \%$ in Flanders, $4.4 \%$ in Wallonia and $22.4 \%$ in Brussels. This method has two biases: it ignores converts (Bousetta / Maréchal 2003; Haddou 2012) and it doesn't allow for the enormous diversity in the day-to-day practice of Islam which has been demonstrated by other research (Dassetto 2011; Torrekens / Adam 2015).

3 Centre pour l'égalité des chances et la lutte contre le racisme, Migrations et populations issues de l'immigration en Belgique, 2013.

4 http://www.npdata.be/BuG/186-Aantal-moslims-gemeenten. 
According to the Muslim Executive of Belgium's figures ${ }^{5}$, there are 68 mosques in Brussels of which 10 are recognized by the state, 76 mosques in Wallonia of which 43 are recognized, and 165 in Flanders of which 28 are recognized. For the 81 mosques recognized by the regions, the federal government pays the salaries of 70 imams. However, not all mosques want to be recognized by the state. In fact, some refuse state scrutiny and don't apply to be recognized by the MEB. They are financed either by their members, or by foreign states, mostly Saudi Arabia via the World Islamic League. The donor has considerable influence over the choice of imam, the theological line, the teaching.

The Moroccan mosques are Maliki Sunnis and the Turkish mosques are Hanafi Sunni. The other traditions of Islam (Shiite, Sufi, Alevi, Suleymani, etc.) are only present in very small numbers (El Battiui / Kanmaz 2004). However, many studies have shown the growing influence of the Muslim Brothers, of Wahhabism and of Salafism in some Moroccan mosques (Maréchal 2008; Dassetto 2011). These mosques join together in umbrella organizations. The Diyanet managed by the Turkish Directorate of Religious Affairs, linked to the Turkish state, brings together half of the Turkish mosques whose management in Belgium is in the hands of the Turkish Islamic Religious Foundation. This group comprises 68 mosques, of which 40 are recognized (Husson / Mandin 2014). The recognized mosques which belong to the Diyanet do not apply for salaries for their imams from the federal state. They receive imams made available by the Diyanet to serve three-year terms. These imams are paid by the Diyanet at a more generous level than that provided by Belgian legislation. The Diyanet also makes financial contributions to its mosques and plays an important role in political representation. The Union of Muslims of Belgium (Rassemblement des Musulmans de Belgique) is an umbrella organization that coordinates the activities of mosques which are members of the Muslim Executive of Belgium (MEB) and promotes the training of new leaders, imams and teachers. It is essentially a grouping of Moroccan mosques and it maintains privileged links with the highest political and religious Moroccan authorities. There are other smaller umbrella organizations serving mosques according to their theological traditions or the nationality of their members (Husson 2007; Husson / Dury 2006).

The federal state finances 17 Muslim prison counselors. These Muslim counselors have been trained by the MEB for the religious dimension of their work and by public institutions for legal and social matters. However, the largest public contribution is the salaries of teachers of Islamic religious education in state schools. There are almost 300 teachers employed in state schools in Flanders and 400 in the francophone part of the country. For almost 20 years, the political debate on leadership training has centered on teachers of Islamic religious education (Boender / Kanmaz 2002). To meet the requirement to organize religious education, from 1975 to 1990 the Islamic and Cultural Center basically brought

5 http://www.embnet.be/Mosquées/tabid/594/Default.aspx. 
teachers in from abroad who didn't speak any of the official languages of Belgium. Most of them did not have the required qualifications and were granted exemption from the usual requirements for reasons of urgency. During the 1990s, in the absence of a representative leadership body, an advisory body appointed by the state managed appointments of teachers of Islamic religious education and limited the numbers of teachers arriving from abroad. Between 1993 and 1997, the Flemish government created an evening course made up of classes in theology, teaching methodology and language. The teachers who refused to take the exam were no longer employed. The interventionism of the Flemish government was also demonstrated by the initiative taken to support a Flemish training scheme for teachers of Islamic religious education. Since 1998, in collaboration with the MEB, the Erasmus University College has offered a three-year bachelor course for which students must study three subjects, one of which is Islam. The design and teaching of the course in Muslim theology and Koranic studies are the responsibility of two teachers nominated by the MEB. The principal challenge was to construct a training course for future teachers of Islamic religious education with the MEB in collaboration with institutions of higher education.

In Wallonia-Brussels, there has not been a comparable experience. Most of the teachers have not had training in the study of religion and of Islam, except for the Turkish teachers who were mostly trained in Turkey. Most of them have a master's degree from a Belgian university and a diploma of competence to teach Islamic religious education from the MEB. The institutions of higher education and the MEB offer further training and professional development conferences. Since 2014, the MEB has initiated discussions with the Theology Faculty of the Université Catholique de Louvain (UCL) with a view to creating an option in Islamic religious education as part of the university's teacher training course. The design of the course program and the nomination of teachers of Islamic religious education depend on the MEB. Unlike what has happened in Flanders, in this case there was no state-led initiative, but rather direct contact between the MEB and UCL. Apart from this, the Center for Interdisciplinary Research on Islam in the Contemporary World at UCL has run a course on Islamic religious studies since 2004, which also includes classes in theology taught by professors from abroad.

While the MEB is the official interlocutor of the state, it is not a permanent base for academic study of Islam. The training courses are offered on a one-off basis. The vision of the MEB is to set up a university faculty of Islamic theology on the model of the university faculty of Protestant theology in Brussels, autonomous but recognized by the state. At present the MEB is also in competition with training courses organized by private institutions, some of which offer "university qualifications", which however are not officially recognized by the state. These private institutions include in particular the Islamic Faculty of Europe ${ }^{6}$, which has

6 http://www.ifeg.be. 
one branch in Flanders and another in Brussels ${ }^{7}$, and the Alkhayria Belgica ${ }^{8}$ association, which owns a European Academy of Culture and Islamic Studies in Belgium. These two institutions offer a "university qualification" made up of three years at bachelor's level and two years at master's level. They also organize various cycles of conferences. The oldest training course in Islamic studies is validated by the European Islamic Institute of the Islamic and Cultural Center of Belgium ${ }^{9}$. The target groups these institutions aim to provide for are imams, teachers of Islamic religious education and Muslim counselors (Piqueray / Nonneman / Timmerman 2009, p. 12-13).

The training of these three "professions" (imam, teacher of Islamic religious education and Muslim counselors) is constantly on the political agenda and at the heart of many political debates and public initiatives. However, it is especially the training of imams that is currently on the political agenda. The public authorities are seeking to support the MEB in its vision of creating a training center for Muslim leadership, but they are also launching initiatives in association with MEB to compete with the many private initiatives that are not controlled by the state and whose normative, religious and political orientations are suspect in the eyes of some politicians. However, a central question remains, which is that of the legitimacy of state involvement to promote the emergence of a training center for Islamic studies centered on theology.

\section{Legitimacy of state involvement in the training of religious leaders}

The question of the training of religious leaders is intimately linked to the question of the relationship between religions and the state. In Belgium, the state does not set any particular conditions for the training of ministers of religion, leaving religious bodies the responsibility for setting their own standards and requirements. This leads to a wide variety of approaches from one religion to another and sometimes also within a single religion. This noninterference by the state in religious matters is historically a relatively recent phenomenon. In many European countries, systems of regulation of the training of religious leaders in general and ministers of religion in particular continued up to the nineteenth century, for example the policy of Joseph II, Emperor of the Habsburg Empire (Kossmann 1988, p. 54) or that of the consulate of Napoléon Bonaparte (Messner 2010).

Compliance with two principles justifies intervention by the state: ministers of religion must contribute to the maintenance of "public order" and "religious peace". To achieve these objectives, ministers of religion must have good quality

7 http://www.faculte-islamique.be.

8 http://www.alkhayria.org.

9 http://www.centreislamique.be/en/homepage. 
training. The question is always in which aspect of the training should the state be involved: theological knowledge or social and civic training? Training of Muslim leaders is on the political agenda mainly because of questions raised about compliance with these two principles. After 9/11 many reports, including some commissioned by the government, showed the dangers which could be stirred up by the teaching of some imams on the subject of maintaining public order and religious peace, to which was now added the fight against radicalism.

The report of the Commission of Intercultural Dialogue set up by the federal government, in February 2004, formulated recommendations for "living together". Among these recommendations was the creation of a Belgian Institute of Islam and a Center of Interfaith Studies to promote dialogue between religious, secularist and other traditions. This should be a "center of research and teaching where people could study on the one hand the methods and rules of Islamic jurisprudence (ijtihaad, usul al fiqh) and the interpretation of religious sources (Koran and Sunnah), and on the other hand the socio-historic dimension of this juridical and theological heritage. This center would combine academic and educational approaches" (Delruelle / Torfs 2005, p. 8). It would also be a public meeting place. However, the justification for this center rested on a double-sided argument: promoting the exchange between diverse currents within Islam and fighting against fundamentalism and radicalism. The report once again makes clear the nonintervention of the state in religious affairs while adding, "That does not mean that religious freedom has no limits".

While one of the arguments justifying the possible interference of public authorities in the management of religion is that of maintenance of public order and religious peace, a new argument was put forward in the report of the Commission Responsible for the Status of Ministers of Recognized Religions ${ }^{10}$ (2006). The involvement of the state could be justified on the grounds that the state finances ministers of religion who according to article 181 of the Constitution offer "moral assistance". This legal provision allows the state to expect certain "vocational skills". While article 21 of the Constitution forbids the state to involve itself in the training of ministers of religion, article 181 does not forbid it to be concerned with the standards of training of ministers of religion, given that their salaries are justified in terms of "moral assistance". In addition to the two traditional arguments relevant to "religious policing" (Boudon 2002), the report adds this more instrumental argument. Because the state pays their salaries, ministers of religion have to meet "quality standards". This argument ultimately leads to proposing supervision of ministers of religion. The report declares the commission's complete satisfaction with the standards of training in all religions except for Islam. It states thus: "the necessary requirements in respect of the training of imams are at times uncertain, and above all, the conditions under which this training is carried out are altogether imprecise, disparate and, more seriously, badly adapted to the

10 Commission made up of academic experts. 
needs of the Muslim community of Belgium, according to the representatives heard by the commission" (p. 32). The commission therefore proposed the creation of Muslim theology colleges in Belgium responsible for the training of imams.

\section{Political initiatives in Flanders}

Following the reports of the two commissions, the Flemish authorities went straight into action. A first report (Piqueray / Nonneman / Timmerman 2008) consisted of a feasibility study on the provision of training for all Muslim leaders. The main conclusions of the report showed the existence, amongst a part of the Muslim community, of the desire for a "Flemish imams' training course". The unstated understanding was that there is an essential commitment to have imams better trained than those currently in office, by giving them an academic training. However, the content and the partnership involved in the creation of this "Flemish imams' training course" remained very vague. The report insisted on the necessity of receiving recognition from the MEB, to offer a qualification comparable to the high level courses available in countries such as Turkey and Morocco. This proposal does not rule out the need to establish this course in consultation with the countries of origin.

The Flemish government of 2009-2014 put this matter back on the political agenda. They wanted to achieve the result of a qualification for imams in consultation with the representatives of the Islamic faith ${ }^{11}$. As so often, the government proceeded in two steps. Firstly they commissioned a study carried out by Debeer, Loobuyck \& Meier (2011) in order to refine the analysis of the training of imams, in particular in a comparative European perspective, and secondly they set up a commission to make recommendations to the government. The commission was made of members of ministerial cabinets ("Education and Training" and "Citizenship and Integration"), representatives from the universities and representatives of the Muslim community, including the MEB. The commission had the task of defining the training needs for Muslim leaders and proposing possible organizational structures for a "Flemish imams' training course". Given the difficulties involved, the commission suggested that the work should proceed in stages.

In the short term, they proposed investment in the training of Muslim leadership at an academic level by offering them a specific teacher training course. In the medium term, it would be advisable to invest in professionalization programs for imams currently active in Flanders, by making use of Dutch language courses, by developing non-religious higher education courses for imams, and by devel-

11 Government Agreement 2009-2014, "Een daadkrachtig Vlaanderen in beslissende tijden”, p. 76. 
oping citizenship courses for imams. The memorandum to the Flemish government ${ }^{12}$ specified that "the professionalization programs have the objective of supporting current ministers of religion in order to strengthen their ties with the society in which they live and work". Finally, in the long term, the commission suggested investing in a complete university course in Islamic religious studies and facilitating the collaboration between higher education and the Flemish imams' training course.

Since 2014, courses in Islamic studies have begun to be offered at university level. The Katholiek Universiteit Leuven (KUL) has organized this by including an option of Islamic theology and religious studies in a one-year master's course in world religions, interreligious dialogue and religious studies. This option makes available a basic training in Islamic theology and religious studies. It is particularly envisaged for Muslim counselors and teachers of Islamic religious education but is definitely not a training course for imams or a complete academic program in Islamic theology and religious studies.

\section{Political initiatives in the Wallonia-Brussels Federation}

The question of training for Muslim leaders was on the political agenda of the government of the Wallonia-Brussels Federation during 2009-2014. The government proceeded in the same way as the Flemish government. In the course of their term of office, they commissioned a feasibility study with a view to "the creation of a public institute for Islamic studies" (Husson / Mandrin 2014). For the government, this institute would be intended for imams and teachers of Islamic religious education and would be responsible for delivering a religious training course integrating the values of equality and liberty. The report presented a review of the existing courses and formulated various possible scenarios for the future. It advocated "the emergence of a European (or Belgian) Islam".

The report emphasized the necessity for a training course for Muslim leadership to cover the religious aspect and social and civic aspect, including language classes. One of the preferred routes would be an interdisciplinary master's including one or more university certificates and a professional development program. This master's could be jointly organized by various universities in the Wallonia-Brussels federation and coordinated by a permanent body (an NGO or a public body). This route is however only achievable with the involvement of the Muslim communities, and in particular the MEB, and with due respect to the academic freedom of the universities. On this basis, the government set up a commission made up of representatives of the universities, experts, and repre-

12 Een opleidingsaanbod islamitische theologie en godsdienstwetenschappen op universitair niveau en een professionaliseringsaanbod voor imams, memorandum by Minister Smet to the Flemish Government 12 July 2013. 
sentatives of Muslim communities drawn from the MEB. Unlike the Flemish commission, there were no members of ministerial cabinets included. The work of the commission will be completed in November 2015. The debates have followed similar lines to those in Flanders: step-wise development towards the goal of an autonomous training institution and development of projects in collaboration between the MEB and the universities, especially UCL, which has been working in this area for a long time.

\section{Religion as security issue}

The Constitution enshrines the settlement between the state and religions. Although we are no longer in the era of "policing of religions" (Boudon 2002), multiple political actions and declarations show that in the specific case of Islam, religious questions are treated as security matters. On the occasion of various sometimes tragic events such as the killing committed at the Jewish Museum of Belgium in May 2014, but also the departure of young Muslims to fight in Syria in 2013, the incitement to hatred promoted by the group Sharia4Belgium in 2013, the Muslim radicalization in the prisons in 2013, and the expression of Muslim radicalism following the killing at Charlie Hebdo in 2015, political responses have been hardline and security-oriented. The suspicion with regard to the teaching of some radical imams has been expressed explicitly and the state, while recognizing that it cannot comment on the religious content of sermons, reaffirms that these may not express ideas contrary to the law and the Constitution. Training for imams is considered as an instrument with which to combat Muslim fundamentalism and radicalism, especially among the young. Thus the training of imams is part of a logic of security and not one of raising their educational standards (Frégosi 2004; Zemni 2006). For the political authorities, these political actions and declarations do not infringe the constitutional principle of the separation of state and religion. Indeed, this separation is only achievable if two of the conditions it is based upon are respected: religions must secure "public order" and "religious peace". The events which have taken place in Belgium and in Europe lead to the view that these conditions are not fulfilled. This justifies public intervention and a response in terms of internal state security. To this is added the argument advanced by the Council of Elders which maintains that the state is entitled to expect professional standards of ministers of religion in their work of moral assistance, in exchange for the payment of their salaries.

Since the events of Charlie Hebdo, the federal state and the regions have implemented programs to combat radicalism. Public interventionism has also been marked at the regional level, responsible for the recognition of mosques and for leadership training. Comparison between the policies of Flanders and of Wallonia-Brussels reveals the same opposition as that observed by Ilke Adam (2013) in the matter of immigrant integration. The policy is more interventionist 
in Flanders and more laisser-faire in the francophone part of the country. The security component of the policy is seen in Flanders in the law for the recognition of places of worship. Thus, one of the criteria for recognition is that the local community should reject any individual who acts in violation of the Constitution or of the Convention for the Protection of Human Rights and Fundamental Freedoms. This criterion is not present in the laws of the Brussels Capital Region and the Walloon Region. Likewise, imams who do not have Belgian citizenship must participate in the mandatory integration program in Flanders. This too is a criterion for the recognition of a place of worship. The dimension of assimilation is much more strongly emphasized in public discourse in Flanders, where lack of knowledge of the Dutch language is a major problem among the imams, also denounced by imams such as Brahim Laytouss ${ }^{13}$, adding to the justification for public intervention.

The initiatives taken by the Flemish and francophone governments have often been criticized on the grounds of the lack of respect for the separation of state and religion, especially on the francophone side. For example, the Islam specialist Felice Dassetto (2014) wrote on his blog that the project in the Wallonia-Brussels federation revives the "Josephinist policy" of religion which contravenes the principle of the separation of state and religion. Jean-Philippe Schreiber (2015) founder of a master's in studies of religions and secularism at the Université libre de Bruxelles (ULB) shares the same analysis and describes the project as "neogallicanism". In contrast, some Muslim elites have celebrated the public intervention and formulated radical proposals (mandatory recognition for all mosques, preaching only in the official languages of Belgium, university qualifications for all imams, etc.) to construct a Belgian Islam for which one of the objectives is to end the superintendence that some foreign countries exercise over Belgian mosques.

Public interventionism is also made possible by the climate of Islamophobia, by the fragmentation of the Muslim community and the institutional fragility of the MEB. Islam is a minority religion and one that is strongly marginalized in the context of multiple controversies (veil, reasonable accommodation, etc.). In this context, it is difficult to propose an alternative to the discourse of security formulated by the political authorities and supported by public opinion. The surveillance practices, such as screening, have also generated distrust of the political authorities within the Muslim communities. In addition, as noted by Farid El $\mathrm{Asri}^{14}$, the "prominence of security" in political discourse and action leads Muslims to feel that they are the victims of discrimination and creates distrust towards any political initiative coming from above.

13 Het Nieuwsblad, 19/01/2015.

14 El Asri, F. (2013, 10 septembre). "La formation des imams en Belgique: pas si vite!" in La Libre Belgique. 10 September 2013, available at http:/www.lalibre.be/debats/ opinions/la-formation-des-imams-en-belgique-pas-si-vite-522e947235703d8e48d3f2b1. 
The fragmentation of the Muslim community stems from the diversity of its religious and national roots. There are Muslim communities which have grown up from the grassroots, in local communities. These communities also embrace a wide diversity of religious practice as well as a diversity of expectations, especially on the part of the imams, who vary a great deal. The younger generations of Muslims are more educated than their parents. Their expectations of the imams are much higher. They are searching for an intense spirituality that they do not always find in the mosques (Husson / Mandrin 2014; Torrekens / Adam 2015), or in imams who have had a limited education in Islamic religious studies, or in those offering a dogmatic approach to the faith. They are looking for imams who understand the daily lives of their faithful and respond to their preoccupations. Some Muslims also expect imams to have the skills to get involved in the life of society (Mukadam / Scoot-Baumann 2010) and in social organization (Jouanneau 2013). Finally, there is also a strong expectation of a deep knowledge of scripture and of the contextualization of Islam in Europe. These expectations show the existence of another cleavage in the Muslim communities: a generational cleavage. These multiple cleavages dividing the Muslim communities make it more difficult to construct a consensual ideal of what an imam should be and how he/she should be trained.

Finally, political interventionism is also a result of the weak legitimacy of the MEB. The successive crises within the MEB especially at the time of the 2005 elections have weakened its power and its credibility among the Muslim communities and in respect of the political authorities. While the 2014 elections were calmer, the fact that a significant number of members of the MEB come from unrecognized mosques or mosques that chose to remain unrecognized raises questions. The MEB wants to get away from its paternalist reputation but has difficulty in formulating a plan for training which could be recognized by the state. This is due to the total lack of consensus within the MEB on this subject. The president of the MEB wanted the subject of imams' training to be excluded from the debates of the commissions (Schreiber 2015) which were set up in Flanders and Wallonia-Brussels, whereas the president of the Congregation of Muslims in Belgium (Dassetto 2014) was pleased that it was included. But the deepest internal division is that between the Moroccans and the Turks. The Moroccan representatives want a university faculty of Islamic studies which would also maintain contacts with the universities of the Arab world, whereas the Turkish representatives linked to the Diyanet do not want this. The latter are satisfied with the current situation whereby imams, even young Turks born in Belgium, follow training courses in Turkey and are then paid by the Turkish state for their work in the role of imam. This internal dissension has caused deadlock and creates the opportunity for state intervention. This shows again the weight of the countries of origin on this sensitive question of imams' training. 


\section{Conclusion}

The training of Muslim leadership, and above all of imams, is a big issue in Europe. The proposals that are currently emerging from the initiatives taken by the Belgian political authorities in collaboration with the MEB and the universities are leading towards training programs for Muslim leadership, with the exception of imams. This is ultimately fairly similar to what has happened in France (Strasbourg, Paris, and Bordeaux). These are general training courses aiming to give an understanding of Islam but none of them is a university-level course for imams. There are two other models in Europe: the German model and the Dutch model (Messner 2015; Fuess 2011; Heuts / Klaver / Van der welle 2012). The German model consists in creating institutes of Muslim theology within the university, offering bachelor's and master's degree courses. At some German universities, endowed chairs for Islamic theology are financed by third parties, among them the Turkish governmental council for religious affairs. This limits chances for the emergence of a European Islam because of its dependence on the country of origin. The Dutch model consists in offering a full university program put together in collaboration with Islamic associations but not with the representatives of Islamic communities. If the programs are too general, this can lead Muslims to discredit the model and turn to other training programs. The plans in Belgium are navigating between these two approaches.

Whichever model is chosen, there remains an essential problem which should not be lost from view during the construction of a training program for imams. The training of imams does not lead them automatically to be appointed to a position. As for Protestants and Jews, and in contrast to Catholics, it is local communities who choose their ministers of religion and not the religious hierarchy which in fact does not exist. Even if a candidate imam has followed a training course recognized by the representative leadership body and the state, he still has to be accepted by the faithful. Therefore all plans for training for imams absolutely must take account of the expectations of local communities and of the faithful.

\section{Bibliography}

Adam, Ilke: 'Immigrant Integration Policies of the Belgian Regions: Sub-state Nationalism and Policy Divergence after Devolution', in: Regional \& Federal Studies, 2013/23 (5), p. 547-569.

Bastenier, Albert / Dassetto, Felice: Media u Akbar. Confrontations autour d'une manifestation. Louvain-La-Neuve 1987.

Beumier, Marc: 'Le statut social des ministres des cultes et des délégués laïques', in: Courrier hebdomadaire du CRISP. 2006/1918.

Blaise, Pierre / de Coorebyter, Vincent: 'L'islam et l'État belge', in: Res publica, 1993/1, p. 35-36. 
Blaise, Pierre: 'La reconnaissance et la représentation de l'islam en Belgique', in: Tribune immigrée, 1998/18, p. 14-22.

Boender, Welmoet / Kanmaz, Meryem: 'Imams in the Netherlands and Islam Teachers in Flanders', in: Shahid W.A.R / Koningsveld P.S. (ed.): Intercultural Relations and Religious Authorities: Muslims in the European Union. Leuven 2002, p. 169-180.

Boudon, Jacques-Olivier: Napoléon et les cultes. Paris 2002.

Bousetta, Hassan: Rompre le silence. Bruxelles 2002.

Bousetta, Hassan / Maréchal, Brigitte: 'L'islam et les musulmans en Belgique. Enjeux locaux \& cadres de réflexion globaux.' Bruxelles 2003.

Center for Equal Opportunities and Opposition to Racism: Engagements pour l'égalité. Actions du Centre. Rapport annuel. Bruxelles 1995.

Center for Equal Opportunities and Opposition to Racism: Migration. Rapport annuel. Bruxelles 2013.

Centre pour l'égalité des chances et la lutte contre le racism: Migrations et populations issues de l'immigration en Belgique, Bruxelles 2013.

Commission Responsible for the Status of Ministers of Recognized Religions: Le financement par l'Etat fédéral des ministres des cultes et des délégués du Conseil central laïque. Bruxelles 2006.

de Coorebyter, Vincent: 'Retour sur la naissance d'un système paradoxal', in: Husson, Jean-Franáois (ed.), Le financement des cultes et de la laïcité: comparaison internationale et perspectives. Namur 2005, p. 91-100.

Dassetto, Felice / Bastenier, Albert: 'Médias U Akbar: confrontations autour d'une manifestation'. Louvain-la-Neuve 1987.

Dassetto, Felice: Le projet de formation de "cadres de l'islam" du ministre Marcourt. Questions et perplexités, 20 décembre 2014, available at: http://www.felicedassetto. eu/index.php/blog-belgique/208-projet-marcourt [07.08.2015].

Dassetto, Felice: L'iris et le croissant. Bruxelles et l'Islam au défi de la co-inclusion. Louvain-la-Neuve 2011.

Debeer, Jonathan / Loobuyck, Patrick / Meier, Petra: Imams en islamconsulenten in Vlaanderen: Achtergrond en activiteiten in kaart gebracht. Antwerpen/Hasselt 2011.

Delruelle, Edouard / Torfs, Ricks: Rapport final. Commission du dialogue interculturel. Bruxelles. Bruxelles 2005.

El Battiui, Mohamed / Kanmaz, Meryem: Mosquées, imams et professeurs de religion islamique en Belgique. Etat de la question et enjeux. Bruxelles 2004.

Fetzer, Joel / Soper, Christofer: Muslims and the State in Britain, France and Germany. Cambridge 2005.

Frégosi, Frank: 'L'Imam, le conférencier et le jurisconsulte: retour sur trois figures contemporaines du champ religieux islamique en France', in: Archives de sciences sociales des religions, 2004/125, p. 131-146.

Fuess, Albrecht: Introducing Islamic Theology at German Universities, Aims and Procedures. Copenhagen University Islam Lecture Series. 13th April, 2011.

Haddou, Aïcha: 'La conversion à l'épreuve de l'Islam', in: Maréchal, Brigitte / El Asri, Farid (eds.): Islam belge au pluriel. Louvain-la-Neuve p. 85-112.

Hertogen, Jan: 'In België wonen 628.751 moslims', in: Indymedia, 12 september 2008; available at: http://www.indymedia.be/en/node/29363 [11.01.2016]. 
Heuts, Lars / Klaver, Jeanine / van der Welle, Inge: Evaluatie Islam- en imamopleidingen in Nederland. Amsterdam 2012.

Husson, Jean-François: La formation des imams en Europe. Etat des lieux. Bruxelles 2007.

Husson, Jean-François / Dury, Julie: Pour une formation des imams en Belgique. Points de référence en Belgique et en Europe. Bruxelles 2006.

Husson, Jean-François / Mandrin, Jérémy: Etude de faisabilité en vue de la création d'un Institut public d'étude de l'islam (IPEI). Liège 2014.

Jacobs, Dirk / Teney, Céline / Rea, Andrea / Delwit, Pascal: 'Voting Patterns among Ethnic Minorities in Brussels (Belgium) during the 2006 Local Elections', in: Acta politica, 2010/45, p. 273-297.

Jouanneau, Solène: Les imams en France. Une autorité religieuse sous contrôle. Marseille 2013.

Kanmaz, Meryem: 'The Recognition and Institutionalization of Islam in Belgium', in: Muslim World 2002/92 (1-2), p. 99-113.

Kingdon, John: Agendas, Alternatives, and Public Policies. Boston 1984.

Kossman, E. H.: The Low Counties 1780-1840. Oxford 1988.

Lijphart, Arend: Conflict and Coexistence in Belgium: the Dynamics of a Culturally Divided Society. Berkeley 1981.

Maréchal, Brigitte: The Muslim Brotherhood in Europe. Roots and Discourses. Leiden 2008.

Messner, Francis: 'Les pouvoirs publics et la formation des cadres religieux en France', in: Messner, Francis / Zwilling, Anne-Laure (eds.): Formation des cadres religieux en France. Une affaire d'Etat? Paris 2010, p. 13-24.

Messner, Francis (ed.): Public authorities and the training of religious personnel in Europe. European Consortium for Church and State Research. Madrid 2015.

Mukadam, Mohamed / Scott-Baumann, Alison: The training and development of Muslim Faith Leaders: Current practice and future possibilities. London 2010, available at: https://www.gov.uk/government/uploads/system/uploads/attachment_data/file/6155/ 1734121.pdf.

Pierson, Paul: Dismantling the Welfare State? Reagan, Thatcher, and the Politics of Retrenchment. Cambridge 1994.

Piqueray, Edith / Nonneman, Walter / Timmerman, Chris: Eindrapport: Haalbaarheidsstudie over een vormingsaanbod voor islamkaders. Antwerpen 2008.

Piqueray, Edith / Nonneman, Walter / Timmerman, Chris: Rapport deel II: Project opleiding in 'Islamitische studies'. Antwerpen 2009.

Potz, Richard / Wieshaider, Wolfgang (eds.): Islam and the European Union. Leuven 2004.

Rea, Andrea: 'La reconnaissance et la représentation de l'islam', in: L'année sociale, 2000, p. 269-275.

Renaerts, Monique: 'L'historique de l'islam en Belgique et la problématique de sa reconnaissance', in: Cahiers de l'Institut de Philologie et d'Histoire Orientales, 1996/3, p. 51-63.

Royal Commissariat on Immigrant Policy: L'intégration: une politique de longue haleine. Volume I. Bruxelles 1989. 
Sägesser, Caroline / Torrekens, Corinne: 'La représentation de l'islam', in: Courrier hebdomadaire du CRISP, 2008/1996-1997.

Sägesser, Caroline. 'Les cours de religion et de morale dans l'enseignement obligatoire', in: Courrier hebdomadaire du CRISP, 2012/2140-2141.

Sägesser, Caroline / de Coorebyter, Vincent: 'Cultes et laïcité en Belgique', in: Dossier du CRISP, 2000/51.

Schreiber, Jean-Philippe: 'Gestion de l'islam: un néo-gallicanisme?', in: Observatoire des religions et de la laïcité, 23 mars 2015; available at: http://www.o-re-la.org/index. php?option $=$ com_k2\&view $=$ item $\& i d=1181 \% 3$ Agestion-de-l'islam-un-néo-gallica nisme-\%3F\&Itemid $=85 \&$ lang $=$ fr $[07.08 .2015]$.

Tihon, André: 'Le financement des cultes en Belgique (1780-2005)', in: Husson, JeanFrançois (ed.): Le financement des cultes et de la laïcité: comparaison internationale et perspectives. Namur 2005, p. 191-200.

Torrekens, Corinne / Adam, Ilke (eds.): Belgo-Marocains, Belgo-Turcs, (auto)portrait de nos concitoyens. VUB/ULB. Bruxelles Fondation Roi Baudouin 2015.

Zemni, Sami: 'Islam between Jihadi Threats and Islamist Insecurities? Evidence from Belgium and Morocco', in: Mediterranean Politics 2006/11 (2), p. 231-253. 